\title{
High mortality of COVID-19 associated mucormycosis in France: a nationwide retrospective study
}

François Danion ${ }^{1}$, Valérie Letscher-Bru ${ }^{2}$, Juliette Guitard ${ }^{3}$, Karine Sitbon ${ }^{4}$, Sarah Dellière ${ }^{5}$, Adela Angoulvant ${ }^{6}$, Guillaume Desoubeaux ${ }^{7}$, Francoise Botterel ${ }^{8}$, Anne-Pauline Bellanger ${ }^{9}$, Gilles Gargala ${ }^{10}$, Fabrice Uhel ${ }^{11}$, Marie-Elisabeth Bougnoux ${ }^{12}$, Victor Gerber ${ }^{13}$, Justin Michel ${ }^{14}$, Marjorie Cornu ${ }^{15}$, Stéphane Bretagne ${ }^{4,5}$, Fanny Lanternier ${ }^{4,16}$ and the COVID-Mucor study group

1 Université de Strasbourg, Hôpitaux Universitaires de Strasbourg, Service de Maladies Infectieuses et Tropicales, Strasbourg, France; Laboratoire d'ImmunoRhumatologie Moléculaire, INSERM UMR_S 1109, Strasbourg, France

2 Université de Strasbourg, Hôpitaux Universitaires de Strasbourg, Laboratoire de Mycologie-Parasitologie, Strasbourg, France

3 Sorbonne Université, Inserm, Centre de Recherche Saint-Antoine, CRSA, AP-HP, Hôpital Saint-Antoine, Service de Parasitologie-Mycologie, F-75012 Paris, France

4 Institut Pasteur, CNRS, Université de Paris, Unité de Mycologie Moléculaire, Centre National de Référence Mycoses Invasives et des Antifongiques, UMR 2000, Paris, France 5 Assistance Publique-Hôpitaux de Paris (AP-HP), Groupe Hospitalier Saint-Louis-LariboisièreFernand-Widal, Laboratoire de Mycologie-Parasitologie, Paris, France

6 Université Paris Saclay, AP-HP, Hôpital Bicêtre, Service des maladies infectieuses et tropicales, Le Kremlin-Bicêtre, France. INRAE, CNRS, AgroParisTech, GQE-Le Moulon, Gif-surYvette, France

7 CHU de Tours, Laboratoire de Mycologie-Parasitologie, Tours, France 8 AP-HP, CHU Henri-Mondor, Laboratoire de Mycologie-Parasitologie, Créteil, France 9 CHU de Besançon, Laboratoire de Mycologie-Parasitologie, Besançon, France $10 \mathrm{CHU}$ de Rouen, Laboratoire de Mycologie-Parasitologie, Rouen, France 11 AP-HP, Hôpital Louis-Mourier, Service de Médecine Intensive et Réanimation, DMU ESPRIT, Colombes, France

12 Université de Paris, AP-HP, Hôpital Necker-Enfants Malades, Laboratoire de MycologieParasitologie, Paris, France 
medRxiv preprint doi: https://doi.org/10.1101/2021.07.05.21260041; this version posted July 7, 2021. The copyright holder for this preprint

(which was not certified by peer review) is the author/funder, who has granted medRxiv a license to display the preprint in perpetuity.

All rights reserved. No reuse allowed without permission.

13 Hôpitaux Civils de Colmar, Service de Réanimation Médicale, Colmar, France

14 Université Aix Marseille, AP-HM, Hôpital de La Conception, Service ORL et Chirurgie Cervico-faciale, Marseille, France

15 Université de Lille, Inserm U1285, CHU Lille, Laboratoire Parasitologie-Mycologie, CNRS, UMR 8576 - UGSF - Unité de Glycobiologie Structurale et Fonctionnelle, Lille, France

16 Université de Paris, AP-HP, Hôpital Necker-Enfants Malades, Service de Maladies Infectieuses et Tropicales, Paris, France

\section{COVID-Mucor study group}

Hamid Merdji (Médecine Intensive et Réanimation, Hôpitaux Universitaires de Strasbourg, Strasbourg, France); Xavier Delabranche (Réanimation Chirugicale, Hôpitaux Universitaires de Strasbourg, Strasbourg); Antoine Parrot (Service de Pneumologie, Hôpital Tenon, AP-HP, Paris); Guillaume Voiriot (Service de Médecine Intensive et Réanimation, Hôpital Tenon, APHP, Paris), Tomas Urbina (Service de Réanimation Médicale, Hôpital Saint Antoine, AP-HP, Paris, France); Alexandre Mebazaa (Réanimation Chirurgicale, Hôpital Saint-Louis, AP-HP); Benjamin Chousterman (Réanimation, Hôpital Lariboisière, AP-HP); Ahmed El Kalioubie (Réanimation, CHU de Lille), Sophie Six (Réanimation, CHU de Lille); Pauline Coulon and Boualem Sendid (Service de Mycologie, CHU de Lille); Nadia Anguel (Réanimation Médicale, Le Kremlin-Bicêtre, AP-HP); Charles Damoisel (Réanimation Polyvalente, Clamart, AP-HP); Charlotte Mussini (Service d'anatomopathologie, Le Kremlin-Bicêtre, AP-HP); Alban Villate (Hématologie, Tours); Jean-Christophe Navellou (Réanimation, CHU Besançon); Christophe Girault (Médecine Intensive et Réanimation, CHU Rouen); Carole Cassagne (Laboratoire de Mycologie, CHU Timone, Marseille); Olivier Augereau (Laboratoire de Microbiologie, Colmar); Dea Garcia-Hermoso, Olivier Lortholary, Alexandre Alanio (CNRMA, Institut Pasteur, Paris); all in France.

Corresponding author: Pr Fanny Lanternier, Institut Pasteur, National Reference Center for Invasive Mycoses and Antifungal, Paris, France.

Key words: COVID-19, mucormycosis, CAM, CAPA

Running title: COVID-19 associated mucormycosis in France 
medRxiv preprint doi: https://doi.org/10.1101/2021.07.05.21260041; this version posted July 7, 2021. The copyright holder for this preprint (which was not certified by peer review) is the author/funder, who has granted medRxiv a license to display the preprint in perpetuity.

All rights reserved. No reuse allowed without permission.

\section{Abstract}

We studied COVID-19 associated mucormycosis based on 17 cases reported nationwide and assessed the differences with India. They differed by frequencies of diabetes mellitus ( $47 \%$ in France versus $95 \%$ in India), hematological malignancies (35\% versus $1 \%$ ), anatomical sites (53\% lung versus $>80 \%$ rhino-orbito-cerebral) and prognosis ( $>80 \%$ mortality versus $<50 \%$ ).

\section{INTRODUCTION}

Coronavirus disease 2019 (COVID-19) has a wide spectrum of severity. Fungal superinfections, notably aspergillosis, can complicate the course of severe COVID-19 with a high mortality [1]. Emerging reports, mainly from India, recently described COVID-19associated mucormycosis (CA-Mucor). In this country, more than 28,000 cases have already been reported and mucormycosis is now a notifiable disease [2]. Outside India, only few case reports have been published from some countries including Europe $[3,4]$. The aim of our study was to describe cases of COVID-19 associated mucormycosis (CA-Mucor) in France and analyze host factors, presentation and outcome.

\section{METHODS}

We conducted a retrospective nationwide study on CA-Mucor. Our network of 59 French mycology laboratories were requested to report CA-Mucor cases diagnosed from March 2020 to June 2021 to the French National Reference Center for Invasive Mycosis \& Antifungals (NRCMA) as part of its surveillance missions. Only cases occurring within the 3 months after COVID-19 diagnosis confirmed by a positive PCR for SARS-CoV-2 were included. Clinical data were recorded anonymously on a standardized case report form. Cases were classified as proven or probable according to EORTC/MSGERC criteria [5], with the addition of diabetes mellitus and dexamethasone prescribed for COVID-19 as host factor and positive Mucorales PCR in serum, blood or plasma as mycological evidence. Date of mucormycosis diagnosis was defined by the first positive sample for mucormycosis. This study is part of the NRCMA official duties which are approved by the Institut Pasteur Internal Review Board (2009-34/IRB) in accordance with French Law. One case has already been published [6]. 
medRxiv preprint doi: https://doi.org/10.1101/2021.07.05.21260041; this version posted July 7, 2021. The copyright holder for this preprint (which was not certified by peer review) is the author/funder, who has granted medRxiv a license to display the preprint in perpetuity.

All rights reserved. No reuse allowed without permission.

\section{RESULTS}

Seventeen patients from eleven centers developed CA-Mucor. Sixteen (94\%) patients were male and the median age was 64 [range 25 - 79]. The median body mass index was 28 [range 19-37].

\section{Underlying risk factors before COVID-19}

Among the seventeen patients, seven (41\%) had classical EORTC/MSGERC host factors for invasive mold infections before COVID-19, including one with solid organ transplantation and six (35\%) with hematological malignancies (HM) [5]. Among the latter, four (24\%) had neutropenia within the last month, one had allogeneic and one autologous hematopoietic stem cell transplant. Overall, four (24\%) patients had diabetes mellitus (DM), including one with HM. Seven (41\%) patients had no risk factors for mucormycosis before COVID-19, but one had pulmonary carcinoma and one underwent chronic dialysis. Three (18\%) patients received immunosuppressive drugs, two (12\%) long-term corticosteroids, and two (12\%) were currently having antineoplastic chemotherapy.

\section{COVID-19}

Sixteen (94\%) patients had severe COVID-19 requiring intensive care unit (ICU). Median time between first COVID-19 symptoms and ICU transfer was 7 days [range 0 - 86]. Management of COVID-19 required corticosteroids for thirteen (76\%) patients, mainly dexamethasone, and tocilizumab for two (12\%). To note, one patient received $\geq 0.3 \mathrm{mg} / \mathrm{kg}$ corticosteroids for $\geq 3$ weeks. Twelve (71\%) patients had high flow nasal cannula oxygen therapy, and thirteen (76\%) had invasive mechanical ventilation. Only two patients had neither high flow nasal cannula oxygen therapy nor mechanical ventilation.

Four (24\%) patients developed DM induced by dexamethasone for COVID-19, meaning that overall eight patients (47\%) had DM. Four (24\%) patients had diabetic ketoacidosis. Eleven (65\%) patients had renal failure, eight $(47 \%)$ requiring dialysis.

\section{Mucormycosis}

CA-Mucor was diagnosed a median of 24 days [range 8-90] after COVID-19 first symptoms, 12.5 days [range 1 - 49] after ICU hospitalization and 16 days [range 1 - 49] after corticosteroid prescription. 
medRxiv preprint doi: https://doi.org/10.1101/2021.07.05.21260041; this version posted July 7, 2021. The copyright holder for this preprint

(which was not certified by peer review) is the author/funder, who has granted medRxiv a license to display the preprint in perpetuity.

All rights reserved. No reuse allowed without permission.

CA-Mucor location was mainly pulmonary $(n=9 ; 53 \%)$, but also digestive $(n=3 ; 18 \%)$, rhinoorbito-cerebral $(n=2 ; 12 \%)$ or disseminated $(n=3 ; 18 \%)$. The six patients with HM had pulmonary $(n=3)$ or disseminated $(n=3)$ CA-Mucor. The rhino-orbito-cerebral forms occurred in one patient with DM and one patient with lung transplant. The three digestive CA-Mucor occurred in patients with no host factors, including no dexamethasone-induced DM.

Twelve patients with a pulmonary location had a chest CT scan evidencing a reversed halo sign in one patient (8\%) with $\mathrm{HM}$ and neutropenia (Figure $1 \mathrm{~A})$, consolidation in ten (83\%) patients, including four (33\%) with a cavitation (Figure 1B), and one with nodules.

\section{Mycology}

CA-Mucor was classified as proven in five (29\%) patients and probable in twelve (71\%). The culture grew Mucorales in samples from eleven (65\%) patients (bronchoalveolar lavage (BAL, $n=5)$, tracheal aspirate and biopsy ( $n=3$, each)). Mucorales PCR assay (adapted from [7] in seven centers, from [8] in one center, and from MycoGENIE ${ }^{\circledR}$, Ademtech, France, in one center) was found positive in fifteen (88\%) patients [serum ( $n=14), \operatorname{BAL}(n=7)$, tissues $(n=3)$, peritoneal fluid $(n=1)]$. Ten patients had more than one positive sample (on different site). PCR was the only means of diagnosis for four patients including two with positive serum and BAL samples. Histology identified hyphae compatible with Mucorales in biopsies from four patients.

Mucorales was identified to the genera or species level by culture or species-specific PCR in fourteen (82\%) patients mainly ( $n=9,64 \%)$ with Rhizopus [Rhizopus microsporus ( $n=6 ; 43 \%$ ), Rhizopus delamar ( $n=2 ; 14 \%)$ and Rhizopus arrhizus $(n=1 ; 7 \%)]$, secondary $(n=4,29 \%)$ with Rhizomucor [Rhizomucor pusillus, Rhizomucor miehei (1 each, 7\%)], and with Lichtheimia sp. in only one case (7\%). All species identified from both culture and PCR were concordant. The cases of Rhizomucor occurred in three patients with $\mathrm{HM}$ and in one patient with pulmonary carcinoma.

\section{Other fungal infections}

Five (29\%) patients developed COVID-19 associated aspergillosis (CAPA), a median of two days [-28-0] before CA-Mucor. All patients with CAPA and CA-Mucor died before week 12 of mucormycosis. One (6\%) patient had invasive candidiasis concomitantly to CA-Mucor. 
medRxiv preprint doi: https://doi.org/10.1101/2021.07.05.21260041; this version posted July 7, 2021. The copyright holder for this preprint (which was not certified by peer review) is the author/funder, who has granted medRxiv a license to display the preprint in perpetuity.

All rights reserved. No reuse allowed without permission.

\section{Treatment and outcome}

Five (29\%) patients died before receiving any specific treatment. Twelve (71\%) patients were prescribed liposomal amphotericin B ( $n=10,59 \%)$, or isavuconazole $(n=2,12 \%)$. Three $(18 \%)$ patients had surgery, two for rhino-orbito-cerebral mucormycosis and one for colonic perforation.

Global mortality was 76\% (13/17) at week 6 and 88\% (14/16) at week 12 (figure 1 C and D). One patient was alive after 43 days but had not yet 12 weeks of follow-up. Death occurred after a median of 34 days [15-119] after the first symptoms of COVID-19 and after a median of 7 days [0-84] after the first positive sample for CA-Mucor.

\section{DISCUSSION}

We here reported seventeen cases of CA-Mucor in France, the largest series from one country outside India $[4,9]$. We observed a large spectrum of clinical presentations and of host factors, and evidenced a high mortality of $>75 \%$ by 6 weeks. These findings differ from our historical (2005-2007) series of 101 mucormycoses in France (Retrozygo, [10]) and from CA-Mucor reported in India $[4,9,10]$.

If we compare mucormycoses risk factors in France from present CA-Mucor series and Retrozygo series, classical EORTC/MSGERC host factors were recorded in $41 \%$ vs. $52 \%$, respectively, and DM in $47 \%$ vs. $32 \%[5,10]$. The frequency of underlying DM was far lower than that recorded in CA-Mucor in India (60\% to 95\%) $[4,9]$. By contrast, the frequency of hematological malignancy in CA-Mucor was higher compared to India ( $35 \%$ vs $1 \%$ ) [9].

Clinical spectrum was also different, with more frequent pulmonary (53\% vs. $28 \%$ ), and less frequent rhino-orbito-cerebral locations ( $12 \%$ vs. $25 \%$ ) in the current series vs. historical Retrozygo Study. The presentation differed clearly from India, where CA-Mucor mainly presents with rhino-orbito-cerebral locations (>80\%) [9]. This difference could be explained by higher prevalence of DM in Indian patients.

Culture and/or histology were positive in $76 \%$ of patients, while diagnosis of CA-Mucor was based only on a positive Mucorales PCR in four patients (24\%). The broad use of Mucorales PCR could partly explain the higher frequency of CA-Mucor in France compared to other 
medRxiv preprint doi: https://doi.org/10.1101/2021.07.05.21260041; this version posted July 7, 2021. The copyright holder for this preprint

(which was not certified by peer review) is the author/funder, who has granted medRxiv a license to display the preprint in perpetuity.

All rights reserved. No reuse allowed without permission.

European countries $[3,7]$. Rhizopus microsporus was the most frequent species in this small series. It is likely though that Mucorales being present in the environment, the species recovered are influenced by the geographic area, as well as the anatomic site and the underlying risk factors explaining the differences in species distribution among studies independently of the COVID context [4].

Twelve week mortality was very high (88\%) in our current CA-Mucor study, by comparison with Retrozygo Study (44\%), and with CA-Mucor in India (40-50\%) $[4,9,10]$. It is also higher than what is reported for CAPA $[1,11]$. This major difference might be partly explained by the higher frequency of pulmonary or disseminated presentations, which are classically associated with a poorer prognosis compared with rhino-orbito-cerebral locations. The severity of COVID-19 itself and the high proportion of patients hospitalized in the ICU might also account for these differences.

The differences in comorbidities, anatomical location and prognosis between our current series and CA-Mucor in India might be explained by a higher frequency of patients with DM in India and the higher burden of mucormycosis, as well as by differences in the management of patients in ICU between the two countries [12].

Despite the multicenter design, the limitations of our study are the small number of cases and the retrospective design. However, epidemiological surveillance in France is based on a reliable and sustained collaboration between French mycologists and the NRCMA. This makes unlikely a major erroneous reporting.

CA-Mucor has a high mortality in this study. Better knowledge, identification and earlier treatments of CA-Mucor might help to improve the prognosis. International studies are warranted to better understand and assess CA-Mucor. 
medRxiv preprint doi: https://doi.org/10.1101/2021.07.05.21260041; this version posted July 7, 2021. The copyright holder for this preprint (which was not certified by peer review) is the author/funder, who has granted medRxiv a license to display the preprint in perpetuity.

All rights reserved. No reuse allowed without permission.

\section{References}

1. Koehler P, Bassetti M, Chakrabarti A, et al. Defining and managing COVID-19-associated pulmonary aspergillosis: the 2020 ECMM/ISHAM consensus criteria for research and clinical guidance. The Lancet Infectious Diseases 2021; 21:e149-e162.

2. Rudramurthy $S M$, Hoenigl $M$, Meis $J F$, et al. ECMM/ISHAM recommendations for clinical management of COVID -19 associated mucormycosis in low- and middle-income countries. Mycoses 2021;

3. Buil JB, Zanten ARH van, Bentvelsen RG, et al. Case series of four secondary mucormycosis infections in COVID-19 patients, the Netherlands, December 2020 to May 2021. Eurosurveillance $2021 ; 26: 2100510$.

4. Hoenigl M, Seidel D, Carvalho A, et al. The Emergence of COVID-19 Associated Mucormycosis: Analysis of Cases From 18 Countries. Rochester, NY: Social Science Research Network, 2021. Available at: https://papers.ssrn.com/abstract=3844587. Accessed 22 June 2021.

5. Donnelly JP, Chen SC, Kauffman CA, et al. Revision and Update of the Consensus Definitions of Invasive Fungal Disease From the European Organization for Research and Treatment of Cancer and the Mycoses Study Group Education and Research Consortium. Clin Infect Dis 2020; 71:1367-1376.

6. Bellanger A-P, Navellou J-C, Lepiller $Q$, et al. Mixed mold infection with Aspergillus fumigatus and Rhizopus microsporus in a severe acute respiratory syndrome Coronavirus 2 (SARS-CoV-2) patient. Infect Dis Now 2021; :S2666-9919(21)00030-0.

7. Millon L, Herbrecht R, Grenouillet F, et al. Early diagnosis and monitoring of mucormycosis by detection of circulating DNA in serum: retrospective analysis of 44 cases collected through the French Surveillance Network of Invasive Fungal Infections (RESSIF). Clinical Microbiology and Infection 2016; 22:810.e1-810.e8.

8. Bialek R, Konrad F, Kern J, et al. PCR based identification and discrimination of agents of mucormycosis and aspergillosis in paraffin wax embedded tissue. J Clin Pathol 2005; 58:11801184.

9. Patel A, Agarwal R, Rudramurthy SM, et al. Early Release - Multicenter Epidemiologic Study of Coronavirus Disease-Associated Mucormycosis, India - Volume 27, Number 9-September 2021 - Emerging Infectious Diseases journal - CDC. Available at: https://wwwnc.cdc.gov/eid/article/27/9/21-0934_article. Accessed 28 June 2021.

10. Lanternier F, Dannaoui E, Morizot G, et al. A Global Analysis of Mucormycosis in France: The RetroZygo Study (2005-2007). Clinical Infectious Diseases 2012; 54:S35-S43.

11. Gangneux JP, Dannaoui E, Fekkar A, et al. High Prevalence of Fungal Infections in Mechanically Ventilated COVID-19 Patients in the ICU: The French Multicenter MYCOVID Study. Rochester, NY: Social Science Research Network, 2021. Available at: https://papers.ssrn.com/abstract=3858565. Accessed 27 June 2021.

12. John TM, Jacob CN, Kontoyiannis DP. When Uncontrolled Diabetes Mellitus and Severe COVID-19 Converge: The Perfect Storm for Mucormycosis. J Fungi (Basel) 2021; 7:298. 
medRxiv preprint doi: https://doi.org/10.1101/2021.07.05.21260041; this version posted July 7, 2021. The copyright holder for this preprint (which was not certified by peer review) is the author/funder, who has granted medRxiv a license to display the preprint in perpetuity.

All rights reserved. No reuse allowed without permission.

Funding: no funding.

Conflict of interest: FD declares personal fees from Gilead outside the submitted work. FL declares personal fees from Gilead and F2G outside the submitted work. Other Authors have nothing to declare. 
medRxiv preprint doi: https://doi.org/10.1101/2021.07.05.21260041; this version posted July 7, 2021. The copyright holder for this preprint (which was not certified by peer review) is the author/funder, who has granted medRxiv a license to display the preprint in perpetuity. All rights reserved. No reuse allowed without permission.

Figure 1. COVID-19 associated mucormycosis in France.

A: Chest CT scan showing a reversed halo sign. B: Chest CT scan showing a cavitation in a consolidation. C: Twelve-week survival after COVID-19 associated mucormycosis diagnosis* $(n=17)$. D: Twelve-week survival according to the host factors.

* Day 0 corresponds to the first positive sample for mucormycosis. One patient was alive after 43 days but had not yet twelve weeks of follow-up. ${ }^{a}$ Classical EORTC/MSGERC criteria were considered before COVID-19. ${ }^{b}$ Other: five patients receiving corticosteroids for COVID-19 $(n=3)$ or without risk factors $(n=2)$. DM: diabetes mellitus.

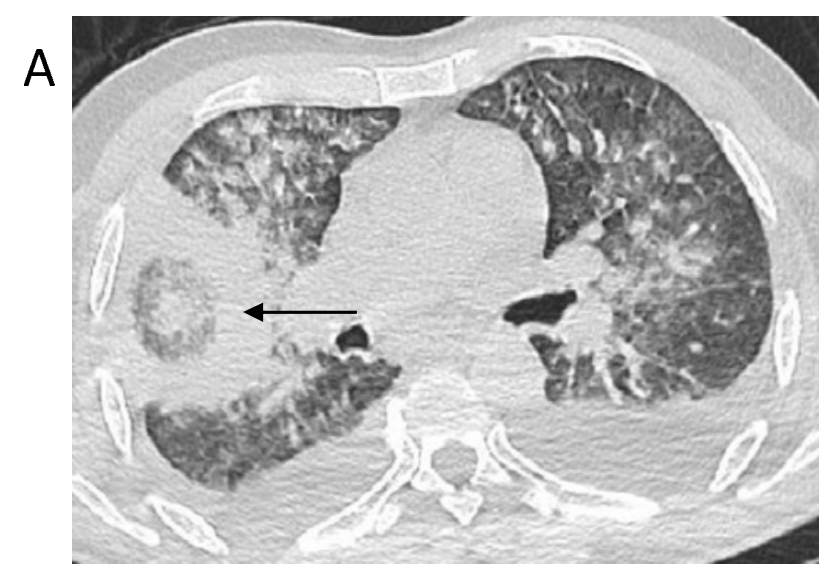

B
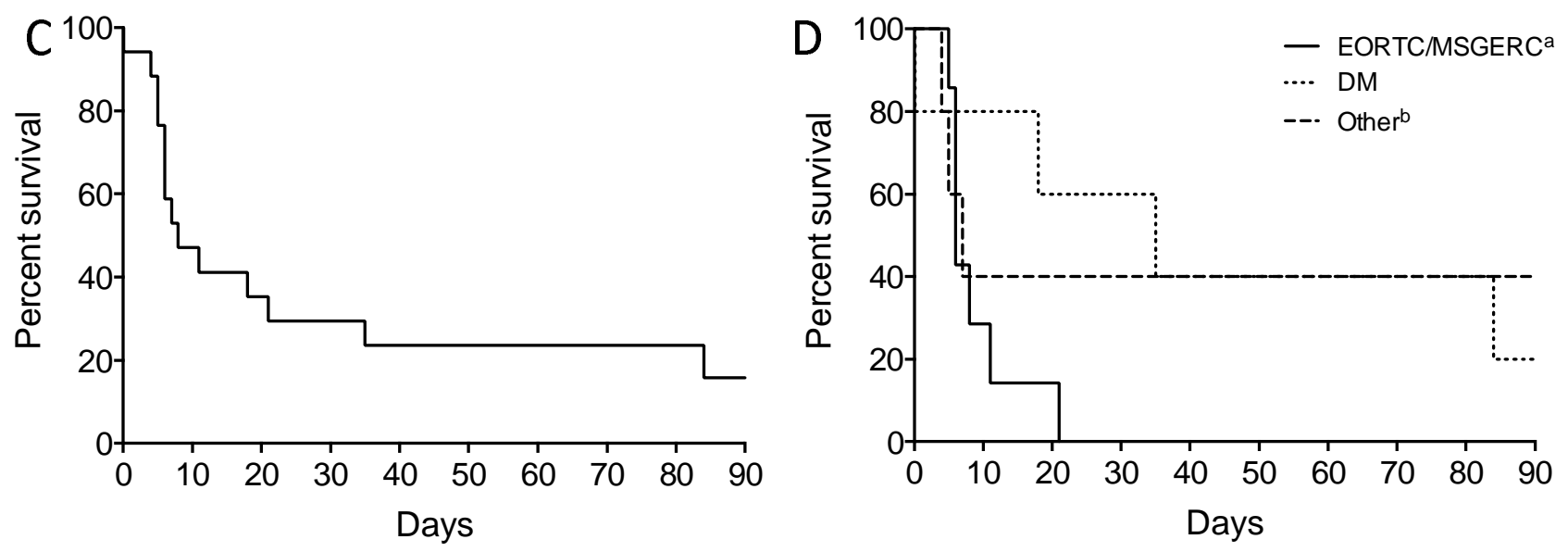